\title{
DEVELOPMENT OF GIFTED EDUCATION AND AN OVERVIEW OF GIFTED EDUCATION IN THE USA, CANADA, EQUATOR AND MEXICO
}

\author{
Eva Reid
}

DOI: 10.18355/PG.2015.4.2.241-247

\begin{abstract}
Education of the gifted individuals dates back to the ancient times, when gifted people were recognized and special education was required for them. But it was not until the $20^{\text {th }}$ century that special and intensive attention was paid to education of the gifted children. Researchers in the United States of America were the pioneers of gifted education and even today, the most research is carried out in the USA. Despite the considerable attention and history of gifted education, the US system receives a lot of criticism. This article maps the history and development of gifted education in the USA and the today's system. Apart of the US system of gifted education, also Canada, Equator and Mexico are mapped.
\end{abstract}

\section{Key words}

gifted education, development of gifted education, gifted education in America, talented, gifted

\section{Historical background of gifted education}

The first pioneers in research and education of gifted children were Terman and Hollingworth in the USA (NAGC, 2014). The view at that time was that clever children could take care of themselves. Hollingworth believed that not only inheritance, but also education and environment were important factors in giftedness and she focused on identification and education of gifted children. She established the term "gifted". Holligworth started experiments with a group of 50 children (age 7-9) with IQ over 155 in the first special class for gifted children called Special Opportunity Class in 1922 in New York. Hollingworth carried out extensive research on family backgrounds, physical, social and temperamental traits of gifted children. She published many articles and a book summarizing her research Giften Children: Their Nature and Nurture in 1926. This book is considered to be the first book on gifted education (Klein, 2002; Dočkal, 2005). Her work carried on with creation of the first school for gifted children age 7-9 Speyer School in 1936. Dočkal (2005) claims, that teaching in this school was only represented by occasional special activities.

In 1922 Terman (1967) carried out still today the longest running longitudinal study of gifted children. The sample was 1528 gifted children, who scored minimum 140 IQ (1\% of general school population). He published 5 volumes of the study, which spanned to nearly 40 years. Gifted children were compared to the control group of unselected children, who were enrolled in the same classes and the gifted children. He claimed that 
gifted children were qualitatively different at school. The gifted were superior to the control group especially in the area of intellectual traits (general intelligence, desire to know, originality, common sense) and volitional traits (willpower, desire to excel, self confidence, prudence). The gifted children were also highly successful in the area of emotional traits (sense of humour and optimism), moral traits (conscientiousness and truthfulness) and social traits (leadership). They did slightly better in aesthetic and physical traits. Jurašková (2003) points out limitations to Terman's research, as all the children were selected by teachers, who usually have tendencies to pick pupils with best marks. Good marks are not reliable criteria for identification of gifted children. The later research proved that teachers' selection usually includes only between 10 to $50 \%$ of gifted individuals. Terman emphasised however, that the gifted child is a product of superior parentage. As a result, a combination of heredity and bringing up environment produces a child who is above average of general population. As Juraskova (2003) mentioned, the Terman's greatest contribution was the finding that environment, emotional and social background of the gifted children are factors, which strongly influence the development of giftedness of individuals.

A deeper interest in educating gifted children was seen during the Cold War, in the time of development of space technologies and defence. The launch of Sputnik in 1957 by the Soviet Union caused a shock in western world, especially in the USA. As a consequence, education of gifted children in the USA became a priority. National Defense Education Act was signed in 1958, which provided funding to US education at all levels, especially with the aim to bolster science, mathematics and technology. This was the first large scale effort in education of gifted children (NAGC, 2014). Special secondary schools for gifted children were founded and new study programmes for intellectually gifted students with the aim to develop creativity were opened at universities (Dockal, 2005).

In 1969 Congress of United States asked the US commissar for education Marland to elaborate a study on education of gifted children. The Marland Report was finished in 1972 and provided the first formal definition of giftedness, which is still used today as the basis of definition of giftedness in the United States (NAGC, 2014). Marland (1972: 2) defined gifted and talented children as those "identified by professionally qualified persons who by virtue of outstanding abilities, are capable of high performance. These are children who require differentiated educational programmes...beyond those normally provided by the regular school programme in order to realize their contribution to self and society". This definition covers general intellectual ability, specific academic aptitude, creative thinking, leadership ability, visual and performing arts and psychomotor ability. Gifted programmes at that time were considered to be elitist, but Marland warned that the bright minority students were particularly vulnerable and could not survive educational neglect and apathy (Loveless, 2006). He reported that gifted children were in fact deprived and could suffer psychological damage and permanent impairment of their abilities to function well if they did not receive appropriate 
attention. Gifted children were believed to have few, if any, special needs (Marland, 1972).

\section{Gifted education today in the USA, Canada, Equator and Mexico}

Overview of school systems of the United States of America, Canada, Equator and Mexico is provided. Definitions, schooling systems and supporting organizations of gifted education in these countries are described in the following chapters. Some information about specific countries' education systems of the gifted is quite elaborate and supported with research findings. Not all the mentioned countries provide detailed information on gifted education and relevant research published in the English language.

\subsection{United States}

Today, the United States' legislation does not include a national policy on gifted education and it does not provide a definition of giftedness and specific requirements for educating the gifted. On the other hand, the US legislation specifies the policy regarding other special needs children (e.g. disabilities). Consequently, each state has its own policy providing gifted education, including definitions, identification, programme options, funding and teacher qualifications. According to Finn and Petrilli (2008), these individual policies result in wide variations. Generally, elementary and middle schools have some version of a gifted and talented programme, high schools have honours, Advanced Placement and International Baccalaureate courses (Farkas, Duffett, 2008). National Association for Gifted Children (NAGC, 2014) provides Gifted Education Programming Standards with rules, policies and procedures for systematic programming for gifted learners, but it is evident from the surveys that less than a half of districts use these standards (Callahan et al., 2014). The federal government also does not provide funding directly to local school districts for gifted programmes and the funding is entirely left to the local governments.

Academically gifted students make up approximately six to ten percent of total student population. These students differ from typical students and the educational programmes should be modified to meet their needs. According to NAGC (2014), most students receive their education in a regular classroom, taught by teachers who have not been trained to teach high ability students. Acceleration, part-time assignment to special classes, grouping according to abilities, skipping classes and taking college level courses are the most common practices in gifted education in the US. Part time, pull out of classes for one to four hours per week, special classes for homogeneous gifted children are the most frequent options for gifted children at elementary and middle schools. Advanced Placement is the predominant programme option for gifted students at the high school level. In 1996 Winner reported that very little attention was paid to the identification and nurturing of gifted children in the USA. She pointed out that other countries like Hungary produced far more than their share of scientists and mathematicians and that a lot of the creative work in the $20^{\text {th }}$

Slavonic Pedagogical Studies Journal Vol. 4 Issue 2, September 2015 
century in the US was done by immigrants from Europe. The findings that America's brightest students failed to compete with international counterparts and that they received no superior education were documented in the report "A Nation at Risk" in 1983 (NAGC, 2014). An educational act "No child left behind" (NCLB) from 2002 was to bring better education to all students, especially to give chances to disadvantaged children. It set standards which should be met at every level of education. However, it was widely criticized (LeBlanc, 2007; Hayes, 2008; Sanders, 2004). LeBlanc (2007) has done considerable research on the impact of the "No child left behind" on gifted children and came to conclusions, that American gifted children continued to decline, or stagnate in their performances, that schools were not able to meet the needs of gifted children, that in fact the NCLB was designed to ensure that no children were left to fail.

The FDR National Teacher Survey in 2008 showed, that within the policy No Child Left Behind (NCLB), the majority (80\%) of teachers set as a priority the academically struggling students, $4 \%$ average students, $5 \%$ academically advanced students and only $9 \%$ reported an equal approach. Teachers claimed that they felt pressure to focus on low achieving students, whilst the top students were neglected (Finn, Petrilli, 2008). The policy objectives of the NCLB were to narrow the achievement gap from the bottom up. However, the principle of the NCLB was that all students deserved fair share of attention and challenges, regardless of their performance level. In reality, the potential of all the students has not been challenged and the focus was on the performance of students who have been "left behind". Finn and Petrilli (2008) argue that if NCLB should survive politically, then no students, even the gifted ones, can be left behind. The National Teacher Survey conducted by Farkas and Duffett in 2008 reveals, that most teachers believe that academically advanced students were not a priority at their schools, that they were bored and under challenged. Teachers believed that their schools did not know what to do with advanced students and they were lacking strategic plans and creative ideas. Teachers thought that the talents of students were going to be wasted. Most teachers mentioned a problem with financing the gifted programmes. Whilst most schools were concentrating on the low achieving students, the teachers of advanced students were told that they need no extra funding as their students "are doing just fine" (Farkas, Duffett, 2008: 54). To sum it up, most teachers in the survey $(77 \%)$ believed that with introduction of NCLB most funding and attention was paid to the underachieving students and the needs of advanced students have been neglected. Silverman (2013) claims, that giftedness is like political football. Once the gifted are in the centre of interest and the other time they are not. The national values shift from the country's striving for excellence to the funds cuts, reflecting the districts' low priority of the gifted as a special needs group. She reports that there are no courses on psychology of giftedness, but school psychologists are responsible for identifying and assessing the gifted children, even though they do not have specific training in the area of giftedness. Based on the several survey findings, many schools and practices are on the same level as 30 or more years ago. Farkas and Duffett (ibid.) believe that it is 
high time to focus and shape the future of gifted education for the $21^{\text {st }}$ century in the USA.

\subsection{Canada}

In Canada, each province and territory is responsible for their own education system. The trend in the whole of Canada is to integrate gifted children in regular classes. There have been established several organisations supporting gifted children. The Association for Bright Children (ABC) of Ontario was found in 1975 and it provides information and support to parents of gifted children and it also represents parents at local school boards and Ontario Ministry of Education and Training (ABC, 2014). Calgary Action for Bright Children (CABC, 2012) was established in 1979 and its aim is to promote growth of awareness, understanding and services for gifted children and their families. They also provide information for programmes for gifted children. There are similar organizations in every province and territory in Canada, which support the gifted education. Even though Canada prefers integration of the gifted in the regular classes, there are also special programmes and even special schools (e.g. Westmount Charter School in Alberta) for the gifted children and they can be found through the organizations for the gifted. The gifted education system has been criticized because the special programmes have been decreased as fewer children receive formal identification and there is no additional funding for gifted children (Mendelson, 2009).

\subsection{Ecuador}

In Ecuador, a special programme "Niños Talentosos, Jóvenes Talensosos" of Sueño Mágico Institute was established in 2006 with the aim to support gifted children. Gifted children are provided with additional tutoring and professional advice. Every new student has to attend recovery and enrichment classes for six months and also special attention is paid to emotional development of children, as they sometimes come from dysfunctional and very poor families. Very interesting is the emphasis which is given to English language education, as a better command of English is considered to be essential for their future prospects. At the end of the eight year programme, students receive support in finding challenging positions in their areas of high capacities (Garaicoa, 2014). Sadly, this programme includes only a very small number of children (18 in 2013 and 20 are planned for 2015) supposedly due to the lack of finances.

\subsection{Mexico}

In Mexico, there is a growing interest in education of gifted children. However the history of education of gifted children is only very short. It was only in 2009, that Mexico recognized the existence of gifted individuals. Since then public and private organizations were created to meet the needs of gifted children. Federation of Giftedness was created in 2013 to raise the attention for the needs of gifted children, with the aim that 
every gifted child in Mexico should receive reliable and professional attention from gifted centres. There are more than 3000 gifted children receiving attention by gifted education centres. There is an increasing awareness among the Mexican population on the importance of special needs for gifted children, but there are still many Mexican states that have no gifted programmes (Anaya, Fratz, Zepeda, 2014).

\section{Conclusion}

From the above described systems of gifted education in the United States of America, Canada, Equator and Mexico, it is obvious, that gifted individuals still receive insufficient attention. The most surprising is the situation in the USA, where a lot of attention and for a long time has been paid to the research of the gifted and still, the system is widely criticised for neglecting the gifted individuals. Canadian system also receives criticism for neglecting gifted individuals and for cutting finances to provide them with adequate education. In Equator and Mexico, the gifted education is quite a new notion and is becoming quite prominent. Even though, considerable support of the gifted children with the help of various organisations is evident in all the mapped countries, adequate gifted education still covers only a small percentage of the gifted population.

\section{Bibliography}

ABC. 2014. The Association for Bright Children of Ontario. Retrieved from: http://www.abcontario.ca/.

AMBROSE, D., VAN TASSEL-BASKA, COLEMAN, L. J., CROSS, T.L. 2010. Unified, Insular, Firmly Policed, or Fractured, Porous, Contested, Gifted Education? In: Journal for the Education of the Gifted. Vol. 33. No. 4, P. 453-478. ISSN 0162-3532.

ANAYA, A., A., FRATZ, I., D.; ZEPEDA, Z.A. 2014. Mexico. In: World Gifted Newsletter. Vol. 32, No. 2. (2014), p. 8. Retrieved from: http://www.world-gifted.org/sites/default/files/WG322.pdf

CABC. 2012. Calgary Action for Bright Children. Retrieved from://www.abccalgary.com/.

CALLAHAN, C. M., et al. 2014. Contributions to the impact of the Javits Act by The National Research Center on the Gifted and Talented. In: Journal of Advanced Academics. Vol. 25, p. 422-444.

COLEMAN, J., CROSS, T., L. 2014. Is Being Gifted a Social Handicap? In: Journal for the Education of the Gifted. Vol. 37. No. 1, P. 5-17. ISSN 01623532 .

DOCKAL, V. 2005. Zamereno na talenty, aneb, Nadani ma kazdy. Praha: Nakladatelstvi Lidove noviny. ISBN 8071068403.

FARKAS, S; DUFFETT, A. 2008. Results from a National Teacher Survey. High Achieving Students in Era of NCLB. Thomas B. Fordham Institute. Retrieved from: http://edex.s3-us-west2.amazonaws.com/publication/pdfs/20080618_high_achievers_7.pdf.

FINN, C., PETRILLI, M. 2008. High Achieving Students in the Era of NCLB. Thomas B. Fordham Institute. Retrieved from: http://edex.s3-uswest-2.amazonaws.com/publication/pdfs/20080618_high_achievers_7.pdf. 
GARAICOA, F. A. 2014. Ecuador. In: World Gifted Newsletter. Vol. 32, No. 2, p. 6. Retrieved from:

http://www.world-gifted.org/sites/default/files/WG322.pdf. .

HAYES, W. 2008. No child left behind: Past, Present and Future. Rowman \& Littlefield Publishers. ISBN 9781578868353

Children in Slovakia. In: XLinguae Journal, Vol. 6. No. 1, ISSN 13378384. JURASKOVA, J. 2003. Zaklady pedagogiky nadanych. Pezinok: Formát. ISBN: 808900511.

KLEIN, A. G. 2002. A forgotten voice: the biography of Leta Stetter Hollingworth. Great Potential Press. ISBN 0910707537.

LALINSKA, M. 2012. Posudenie cudzojazycnej kompetencie ziakov na vystupe z 1. stupna ZS v SR. In: XLinguae Journal. Vol. 5. No. 4. (2012). ISSN 1337-8384.

LEBLANC, K. 2007. Principals' Perceptions of No Child Left Behind's Impact on the Education of the Gifted and Talented Students. Dissertation. College of Education and Behavioral Sciences, School of Educational Research, Leadership, and Technology Educational leadership.

LOVELESS, T. 2006. The 2006 Brown Center report on American Education: How well are our Students Learning? Washington, DC: The Brookings Institution.

MARLAND, S. 1972. Marland Report: Education of Gifted and Talented. Retrieved from: https://www.valdosta.edu/colleges/education/psychologyand-counseling/documents/marland-report.pdf.

MENDELSON, R. 2009. No room for gifted kids. In: Maclean's. Retrieved from: http://www.macleans.ca/news/canada/no-room-for-gifted-kids/.

NATIONAL Association for Gifted Children (NAGC) 2014. A Brief History of Gifted and Talented Education. Retrieved from: http://www.nagc.org/resources-publications/resources/gifted-educationus/brief-history-gifted-and-talented-education.

SANDERS, A. 2004. A Summary of Conclusions Drawn from Longitudinal Analyses of Student Achievement Data over the Past 22 Years. Paper presented to Governors Education Symposium, Ashville, NC. Retrieved from: http://www.sas.com/resources/asset/hunt_summary.pdf.

TERMAN, L. M. 1967. The gifted group at mid-life; Thirty-five years' follow-up of the superior child, (Genetic studies of genius). Standform University Press.

WINNER, E. 1996. Gifted children: Myth and Realities. New York: Basic Books. ISBN: 465017592.

Mgr. Eva Reid, PhD.

Constantine the Philosopher University in Nitra

Faculty of Education

Department of Language Pedagogy and Intercultural Studies

Drážovská cesta 4, 94974 Nitra

Slovakia

ereid@ukf.sk 